\title{
Luoteisvenäläiset nuoret kanssa- ja vertaistutkijoina
}

Meri Kulmala \& Anna Fomina

Venäjäisessä lastensuojelussa on meneillään paradigman muutos, joka seuraa globaaleja kehityskulkuja pyrkien purkamaan sijaishuollon laitoshoidon (deinstitutionalisaatio), jonka on todettu huonosti edistävän lasten ja nuorten integroitumista yhteiskuntaan. Yksi uudistuksen painopisteistä onkin kehittää jälkihuoltoa eli lastensuojelusta itsenäistyvien nuorten tukimuotoja. Arktisten nuorten hyvinvointia tarkastelevassa tutkimushankkeessa Live, Work or Leave? Youth Wellbeing and the Viability of (Post)extractive Arctic Industrial Cities in Finland and Russia olemme kiinnittäneet katseemme luoteisvenäläisiin jälkihuollosta itsenäistyviin nuoriin ja heidän toimijuuteensa ja pyrkineet ymmärtämään, minkälaisen tuen nuoret itse kokevat tarpeelliseksi ja hyödylliseksi tässä itsenäistymisen vaiheessa. Olemme hankkeessa tehneet kanssa- ja vertaistutkimusta kahdella Luoteis-Venäjän alueella yhdessä vastikään eri sijaishuollon muodoista itsenäistyneiden nuorten kanssa. Esittelemme tässä esseessä tutkimusasetelmaamme ja pohdimme sen tuomia hyötyjä ja haasteita.

Ihmistieteissä erilaiset osallistavan tutkimuksen (participatory research) menetelmät ovat yleistyneet erityisesti 2000-luvulla. Osallistavassa tutkimuksessa ne, joita tutkitaan, eivät toimi vain tutkijan informantteina, vaan subjekteina ja toimijoina osallistuen tutkijan ohjauksessa tiedontuottamisen prosessiin. Osallistavassa tutkimuksessa on tavoitteena yhdistää kokemustieto ja teoreettinen tieto. Ajatellaan, että tutkittavat ovat oman elämänsä ja esimerkiksi heitä koskevan palvelujärjestelmän parhaita asiantuntijoita. Tavoitteena on saada (marginaalissa olevan) ääni kuuluviin ja edesauttaa ryhmään kuuluvien yksilöiden toimintaa: pyritään niiin heidän äänensä kuin toimijuutensa vahvistumiseen. Tutkimusote on 
siis ideologialtaan varsin emansipatorinen. Osallistavalle tutkimukselle on tyypillistä pyrkimys tuottaa tietoa niin päätöksentekoon kuin palvelujärjestelmiin, ja se pyrkii tyypillisesti yhteiskunnalliseen vaikuttamiseen. Tässä mielessä osallistava tutkimus tulee jossain määrin lähelle toimintatutkimuksellista otetta.

Osallistavan tutkimuksen yleistyminen liittyy laajempaan yhteiskuntatieteiden reflektiiviseen käänteeseen, joka pyrkii tiedostamaan tutkimuksen tekoon liittyviä positioita ja valtasuhteita, mikä on tyypillistä myös feministisille metodologisille pohdinnoille. Yksi osallistavan tutkimuksen periaatteista onkin kyseenalaistaa sellaisia tutkimukselle tyypillisiä epäsymmetrisesti jakautuneita valtasuhteita kuin tutkija-tutkittava tai haastattelija-haastateltava, joissa ensimmäisillä ajatellaan olevan kyky eli valta oikeanlaiseen tietoon. Tiede ja tutkimus ovat keskeisiä vallankäytön välineitä: niissä määritellään, kenen tieto on "oikeaa" tai "totta" (Pyyry 2012, 36). Tässä mielessä osallistavan ja erityisesti eri kanssatutkijuuden muodot ovat osa tutkimuksen ja tiedon demokratisoitumista.

Viime vuosina onkin alettu suosia niin sanottuja kanssa- ja vertaistutkijuuden menetelmiä. Kanssatutkijuudella (co-research) tarkoitetaan tutkimuksen kohteena olevien ihmisten osallistumista tutkimuksen toteuttamiseen kyvykkäinä toimijoina, joilla on tieto omasta maailmastaan (Pyyry 2012, 37). Kanssa-sana korostaa tutkijan ja tutkittavien yhteistoimintaa tutkimuksen eri vaiheissa. Vertaistutkijuudessa (peer research) puolestaan korostuu kaksi näkökulmaa vertaisuuteen. Ensinnäkin se voidaan ymmärtää tutkijan ja tutkittavan tasavertaisuutena, jolloin tutkimuksen kohteena olevat vertaistutkijat ovat mukana tutkimusprosessissa aivan sen alusta loppuun, tutkimusaiheen valinnasta analyysiin. Vertaisuudella voidaan viitata myös vertaistutkijan ja vertaistutkittavan suhteeseen, jolloin tutkitaan vertaisia, eli vaikkapa nuoret nuoria, eläkeläiset eläkeläisiä tai kehitysvammaiset kehitysvammaisia. Samankaltaiset kokemukset tuovat esimerkiksi haastatteluun keskinäistä ymmärrystä ja samaa kieltä, jonka avulla voi kommunikoida ja tuottaa tutkittujen omaa ajatteluaan tutkimusaineistoon (vrt. Törrönen \& Vauhkonen 2012, 9).

Osallistava lähestymistapa on saanut osakseen kritiikkiä esimerkiksi sen mukanaan tuomasta mahdollisuudesta hyväksikäyttää tutkittavien osallisuutta tutkijan tarkoitusperiin. Voimaannuttamisessa (empowerment) ei saa olla kyse siitä, että valtaa siirretään yhdeltä ryhmältä (tutkijoilta) toiselle (tutkittaville) ainoastaan silloin, kun se hyödyttää ensimmäistä ryhmää (Kilpatrick yms. 2007, 352). Kuten Pyyry $(2012,37)$ on todennut, ei voimaannuttamisen lähtökohtana tulisikaan olla yksilöiden tai ihmisryhmien kehittäminen vaan toimintatapojen muutos kohderyhmän aktiivisen osallistumisen kautta. Eettisten kysymysten keskeisyyttä ei voi liiaksi korostaa, mikä korostuu entisestään silloin, kun toimitaan haavoittuvassa tilanteessa olevien ihmisten, vaikkapa lasten ja nuorten kanssa.

Haasteista huolimatta kanssatutkimukselliset menetelmät lisääntyvät eri tieteenaloilla ja eri ryhmien kanssa. "Ei mitään meistä ilman meitä" on ollut jo pitkään vammaistutkimusta määrittävä periaate (Walmsley \& Johnson 2003). Viime vuosina on keskusteltu paljon erityisesti lasten ja nuorten näkökulmien huomioonottamisesta. YK:n lasten oikeuksien sopimus ja sen luoma poliittinen ilmapiiri korostavat demokraattista osallisuutta ja aktiivista kansalaisuutta. Päätöksenteossa ja palveluiden järjestämisessä tulee enenevässä määrin kuulla lapsia ja nuoria. Lasten ja nuorten osallistuminen omaa elämäänsä koskeviin päätöksiin nähdään siis keskeisenä ihmisoikeuskysymyksenä. Tämänkaltaisen ajattelun yleistyminen on tehnyt osallistumista korostavista metodologisista viitekehyksistä enemmän säännön kuin poikkeuksen lapsia ja nuoria koskevassa sosiaalitieteellisessä tutkimuksessa (Bradbury-Jonesin \& Taylorin 2013, 160). Venäjä-tutkimuksessa osallistuvat tutkimusotteet ovat toistaiseksi harvinaisia. 


\section{Kanssatutkimus luoteisvenäläisten sijaishuollosta itsenäistyneiden nuorten hyvinvoinnista}

Tutkimuksemme avainkäsite on subjektiivinen toimijuus eli nuoren oma käsitys oman toimijuutensa mahdollisuudesta, "minäpystyvyydestä" suhteessa tulevaan. Nuoren siirtymä itsenäiseen elämään on aina erityinen elämänvaihe, joka voi olla samanaikaisesti niin monenlaisten mahdollisuuksien kuin haavoittuvuuksien paikka nuoren elämänkulun kannalta. Sijaishuollosta itsenäistyvillä nuorilla siirtymä tapahtuu tyypillisesti muita nuoria aiemmin ja nopeammin ja usein ilman takaisin palaamisen vaihtoehtoa. Tällöin kysymys heidän selviytymis- ja sopeutumiskyvystään eli resilienssistään (ennakoimattomissa) muutostilanteissa kytkeytyy subjektiivisen toimijuuden käsitteeseen: vahva usko omaan kykyyn vaikuttaa asioihin auttaa jatkamaan pahan paikan tullen (Hitlin \& Johnson 2015).

Toisessa tutkimushankkeessamme olemme tutkineet lastensuojelu-uudistuksen tuomaa ideologista ja institutionaalista muutosta. Tämä nuorisohanke toi mukanaan mahdollisuuden politiikkaohjelmien ja instituutioiden lisäksi tarkastella, mitä uudistus merkitsee ihmisten eli lasten ja nuorten tasolla. Koska tutkimus tarkasteli nuoria ja heidän subjektiivista toimijuuttaan, oli mahdotonta ajatella, että tutkimusta tehtäisiin ilman nuoria. Jouduimme kuitenkin melko lailla pohtimaan sitä, miten nuoret osallistuisivat tutkimukseemme. Haaveilimme teatterin tai elokuvan teosta, mutta jouduimme toteamaan, että se, mitä me osaamme tehdä, on laadullinen tutkimus. Palaamme tuonnempana vielä kysymykseen, miksi juuri kanssatutkimus tuntui sopivalta. Nyt esittelemme lyhyesti, mitä oikein olemme tehneet.

Aineistomme koostuu yhteensä 45 sijaishuollosta itsenäistyneen 18-24-vuotiaan nuoren teemahaastattelusta kahdella Luoteis-Venäjän alueella. Näistä yhteensä 15 on meidän tutkimusryhmämme tekemiä ja 30 nuorten itsensä tekemiä vertaishaastatteluja. Haastattelemiemme nuorten joukosta saimme mukaan kanssatutkijoiksi seitsemän nuorta, jotka ovat tehneet vertaishaastatteluja. Nuoret koulutettiin haastattelujen tekemiseen: aluksi kasvokkain ja tämän jälkeen useissa Skype-sessioissa. Koulutus piti sisällään opastusta laadullisiin haastatteluihin sekä ohjeistusta ja keskustelua monenlaisista hyvin keskeisistä eettisistä kysymyksistä. Haastattelijoille annettiin mahdollisuus vaikuttaa myös haastattelujen sisältöihin ja muotoiluihin.

Nuorten tekemien pilottihaastattelujen jälkeen kävimme tätä ensimmäistä haasttelukokemusta yhdessä läpi. Haastattelujen tekeminen ei ollut ollut helppoa, mikä näkyi myös haastattelujen laadussa: niin puhetta kuin syväinformaatiota oli aika vähän. Keskityimmekin nyt entistä enemmän opastamaan vuorovaikutuksellisissa kysymyksissä, kuten siinä miten haastateltavan puhetta voi tukea. Vasta tässä vaiheessa nuorilla heräisi kysymyksiä ja kommentteja haastattelurungon suhteen. Kuten eräs nuorista totesi: "Teoria on teoriaa ja käytäntö oli sitten toista". Paperilla kaikki tuntui loogiselta ja näytti helpolta, mutta haastattelun tullen ei kaikki toiminutkaan. Kysymyksiä muotoiltiin uudelleen.

Kaikki kanssatutkijanuoret löydettiin paikallisten lastensuojelujärjestöjen avustuksella. Olemme jo aiemmassa tutkimuksessa tehneet tiivistä yhteistyötä käytännön toimijoiden kanssa ja koimme, että nuorilla on oltava joku paikallinen tukipiste, johon he luottavat ja johon meillä tutkijoilla on luottamukselliset suhteet. Järjestöistä onkin ollut paikallinen koordinaattori, joka on avustanut haastattelijoita sekä jonka puoleen haastateltavat ovat voineet kääntyä. Jos nuorilla syntyy mietteitä, huolia ja tunnereaktioita, on lähellä oltava joku ja on tiedettävä kenen puoleen kääntyä. Tällaisen tukihenkilön löytyminen on ollut meille tutkijoille ehto, sillä sekä haastatteluja tehneissä että haastatelluissa nuorissa haastattelut voivat herättää monenlaisia tunteita; kysymykset kun käsittelevät heidän omaa elämäänsä. Haastattelurunko 
koostui muutamista nuoren elämänkaarta mukailevista teemoista, kuten biologinen perhe, elämä sijoituspaikassa, koulu ja opinnot, työelämä, asuminen, vapaa-aika ja harrastukset, läheiset suhteet, arvio tyytyväisyydestä omaan elämäänsä ja tulevaisuudensuunnitelmat. Kaikkien elämänvaiheiden osalta on tavoiteltu tietoa siitä, mikä on ollut nuoren osallisuus päätöksentekoon kussakin käännekohdassa ja minkälaista tukea nuori on saanut ympäriltään.

Kanssatutkijoidemme kanssa tehdään ekskursio Suomeen tutustumaan nuorisotyöhön ja nuorille suunnattuihin palveluihin. Ensimmäisen ryhmän kanssa tämä matka on jo tehty, ja se oli äärimmäisen antoisa niin meille kuin nuorille. Osalle nuorista kyseessä oli elämän ensimmäinen ulkomaanmatka ja näin se oli monelta osin merkittävä ja ajatuksia herättävä. Yksi nuorista tosin oli ollut leirillä Suomessa lapsena. Kävimme kyseisessä leiripaikassa, mikä toi mukanaan niin muistot kuin myös asiantuntija-roolin nuoren toimiessa oppaanamme leirikeskuksessa.

Matkalla nuorten kanssa pidettiin myös fokusryhmäkeskustelu, jossa he reflektoivat kokemustaan tutkimukseen osallistumisesta. He esittivät myös terveisiään tukijärjestelmille ja päätöksentekijöille. Myös tässä yhteistyö paikallisten järjestöjen kanssa on ensiarvoisen tärkeää, sillä heidän kauttaan nuorten kokemuksia voidaan viedä tukimuotojen tasolle. Toisella alueista olemme jo järjestäneet käytännön toimijoiden kanssa seminaarin, joissa tutkimuksen tuloksia esiteltiin. Alueen keskeiset lastensuojelun toimijat kokivat, että tutkimuksemme löysi monia keskeisiä ongelmakohtia. He aikovatkin kirjoittaa tutkimuksemme pohjalta strategiapaperin, jonka avulla kommunikoidaan muutostarpeista vastaavien ministeriöiden suuntaan. Tämä luonnollisesti ilahduttaa meitä, koska yhteiskunnallinen vaikuttavuus on yksi yliopiston perustehtävistä.

\section{Miksi kanssatutkimus?}

Kuten kanssatutkimuksessa yleensä, tavoitteemme on ollut ottaa nuoret mukaan tiedontuotantoon toimijoina. Nuorten osallistamisen tarkoituksena on ollut korostaa nuoria henkilökohtaisen kokemuksensa kautta oman elämänsä sekä sijais- ja jälkihuollon asiantuntijoina ja samalla tarjota joitakin hyödyllisiä, mahdollisesti työelämässä hyödynnettäviä työkaluja (kuten haastattelu- ja vuorovaikutustaidot; todistukset osallistumisesta). Olemme ajatelleet, että asiantuntijuus ja työkalut voisivat parhaimmillaan toimia voimaannuttavana kokemuksena näille koviakin kokeneille nuorille. Kanssatutkijuus voisi siis mahdollisesti vahvistaa näiden nuorten toimijuutta ja heidän omaa käsitystään toimijuudesta - eli juuri sitä samaista toimijuutta, jota tutkimuksemme kokonaisuudessaan pyrkii ymmärtämään.

Tavoitteenamme on myös asioiden tilaan vaikuttaminen. Olemme halunneet antaa nuorille äänen ymmärtääksemme niitä tukimuotoja, jotka ovat olleet heidän näkökulmastaan tärkeitä ja hyödyllisiä sijaishuollon aikana ja erityisesti itsenäistymisvaiheessa. Se, että nuoret itse osallistuvat tiedontuotantoon palvelujärjestelmän onnistumista ja kompastuskivistä, tuntuu herättävän enemmän kiinnostusta kuin se, että tutkimusryhmämme lausuisi jotain ilman nuoria. Prosessi on vielä kesken, mutta kuten yllä totesimme, toistaiseksi käytännön toimijat ovat kokeneet saavansa tutkimuksestamme tärkeää tukea toiminnalleen.

Olemme ennen kaikkea pyrkineet selättään epäsymmetrisiä valtasuhteita. Kenellekään ei varmasti ole vaikea nähdä niitä monitasoisia epäsymmetrioita tilanteessa, jossa keskiluokkaiset (ja osin keski-ikäiset) akateemisesti koulutetut yliopistoissa työskentelevät naiset haastattelevat parikymppisiä sijaishuollosta itsenäistyneitä nuoria. Monissa kohtaa puhumme hyvin eri kieltä - Merin kohdalla ihan konkreettisestikin, sillä venäjä on hänelle vieras kieli, 
ja vaikka myös hän on haastatellut venäjäksi, on ulkomaalaisuus lisännyt asymmetriaa. Kyse ei kuitenkaan ole pelkästään iästä ja asemasta, vaan koemme, että myös ajattelussa on eroja. Kuten eräs professorikollegamme asian ilmaisi:

Olen tutkinut akateemisen urani keskiluokkaisia äitejä. Ymmärrän täysin, mistä he puhuvat ja miten he ajattelevat. Näissä nuorten haastatteluissa tapahtuu usein jotain kummallista. Tarina saa käänteen, jota en ymmärrä.

Tämä ristiriita oli yksi niistä keskeisistä lähtökohdista, miksi päädyimme siihen, että saatamme saavuttaa jotain uudenlaista ymmärrystä, jos nuoret puhuvat nuorten kanssa. Jatkossa tulemme systemaattisesti tarkastelemaan haastatteluja erityisestä vertailevasta näkökulmasta: onko meidän ja nuorten tekemissä haastatteluissa eroa siinä, mistä ja miten meille aikuisille tutkijoille ja vertaisnuorille puhutaan?

Yllä esitetyt seikat motivoivat meitä sosiologeja ryhtymään tämänkaltaiseen tutkimukseen. Mitkä olivat kanssatutkijanuorten syyt ryhtyä moiseen? Osa motiiveista liittyi tulevaan urasuunnitteluun, kuten eräs kanssatutkijoistamme totesi: "Olen tuleva journalisti. Haastattelujen tekeminen on osa tulevaa työtäni.” Toinen puolestaan halusi kehittää itseään ja päästä yli vaikeudesta keskustella tuntemattomien kanssa:

\begin{abstract}
Poikaystäväni on armeijassa ja päätin käyttää tämän vuoden itseni kehittämiseen. Yritän osallistua moneen kaikkialla, olen monilla kursseillakin. Että olisi liikettä. Olen aika ujo ihminen ja minun on usein vaikea puhua tuntemattomien kanssa. Ajattelin että jos kokeilen tehdä haastatteluja, ehkä se helpottuu. (...) [Haastattelua tehdessäni] mietin, että mikä haastattelu tämäkin olisi, jos olen vaan hiljaa. Nämä kysymykset on kysyttävä joka tapauksessa... ja niin vain kokeilin ja kysyin.
\end{abstract}

Kyseinen nuori kokikin oppineensa prosessissa paljon. Hänen tekemiensä haastatteluiden translitterointeja lukiessa on välillä vaikea uskoa, että tämä olisi ollut hänelle vaikeaa: mielestämme erityisesti hänen tekemänsä haastattelut ovat hienon keskustelevia. Myös muut haastattelijanuoret kokivat saaneensa osallistumisesta monenlaista hyötyä. Esimerkiksi sosiaalityötä opiskeleva nuori kertoi, että tuntui mukavalta tuntea olonsa hyödylliseksi, kun pystyi parhaassa tapauksessa neuvomaan haastateltavaa:

Yhdessä haastattelussa oli tosi kiinnostavaa, kun selitin hänelle tämän oikeuksia. Miten hän voi jatkaa opiskeluja, koska hänellä oli siinä kohtaa isoja kysymyksiä, ei tiennyt minne jatkaa.

Tämä tunne on kannustava myös tulevan ammatti-identiteetin näkökulmasta. Nuoret pitivät tilaisuutta osallistua tutkimukseen mahdollisuutena kehittyä ja saada vuorovaikutustaitoja ja työelävalmiuksia (myös Kilpatrick ym. 2007). Nuoret kokivat myös hyötyvänsä siitä, että he saivat osallistumisestaan kansainväliseen tutkimushankkeeseen työtodistukset. 


\section{Helpot ja vaikeat teemat, oikeat ja väärät valinnat}

Haastatteluiden tekeminen ei luonnollisesti aina ollut helppoa. Kun asiaa tarkastelee eri haastatteluteemojen kautta, oletetusti biologisesta perheestä oli vaikeinta puhua. Olimme käyneet tätä teemaa läpi ennen haastatteluja ja korostaneet sen sensitiivisyyttä sekä sitä, että haastateltavalla on kaikki oikeus olla puhumatta jostain ja vaikka keskeyttää haastattelu. Eräs kanssatutkijoistamme kertoikin, että yhdessä haastattelussa "yksi kiersi kaikki ne kysymykset" biologisesta perheestä. "Ymmärsin, että parempi olla kysymättä enempää”, hän jatkoi. Toiselle tämä oli ollut haastavampaa hyväksyä:

\footnotetext{
Minulle tuli tunne epätäydellistä haastattelusta, kun ihminen sanoo 'minun äiti kuoli' ja siinä kaikki. Ja itseä joku pidättelee siinä teemassa, haluat tietää jotta haastattelu olisi kokonaisempi (...) Jokin tärkeä osa puuttuu, jotain ei riitä.
}

Tulevaisuudesta oli puolestaan ollut kiinnostavaa puhua, kuten eräs nuori kertoi: "Minusta oli kaikista kiinnostavinta, mitä he haluavat isona. Missä he ovat 5-10 vuoden päästä." Kanssatutkijanuoret kuvasivat myös sitä, miten helppoa oli suhtautua positiivisesti, jopa kehua ja kannustaa, "kun joku kertoi 'tein sellaisen ja sellaisen valinnan' ja kun se valinta oli oikea”. Niin sanottuihin huonoihin valintoihin puolestaan oli vaikeampi suhtautua, joskin nuoret kokivat kyenneensä olemaan näyttämättä negatiivisia reaktioitaan. Eräs nuori kertoi oppineensa prosessin aikana hyväksymään erilaisia valintoja:

\footnotetext{
Ajattelin ensin, että kokkiko? Siis oikeasti? Ja vielä kaikista huonoin koulu? Lopulta lakkasin arvostelemasta ihmisiä. Ymmärsin, että hitto, kaikki ovat erilaisia (...) Minua on auttanut se, ettei pidä antaa arvosanaa. Sen kun vain kuuntelet ja ajattelet, että näinkin voi olla.
}

\section{Normitettu polku ja hiljaisuudet paikat}

Yllä esitetystäkin käy ilmi, että nuorten elämää ja itsenäistymistä ohjaa enemmän tai vähemmän ääneen lausutusti normitettu polku, jolta poikkeamia pidetään huolestuttavina asioina (vrt. Furlong 2013). Ihan niin kuin muiden nuorten, jälkihuollosta itsenäistyvien nuorten oletetaan muuttavan omilleen, opiskelevan ja näiden opintojen johtavan ennen pitkää työelämään. Tähän suuntaanhan me aikuissosiologit sen enemmittä kyseenalaistuksitta suuntasimme haastattelujen kulkua. Samalla tapaa niistä kanssatutkijanuorten oli helpompaa kysyä ja puhua. Se, että kohdistimme katseen siihen, mistä oli helppo puhua, sai meidät huomaamaan, että haastatteluissa on myös hiljaisuutta.

Etnografinen tutkimus (esim. Mazzei 2007) onkin usein osoittanut, että todennut, että olennaista voi olla se mistä haastattelussa ei puhuta. Vaikenemiselle voi olla monenlaisia syitä. Tutkimuksessamme hiljaisuutta näyttää esiintyvän erityisesti silloin, kun poiketaan normista. Esimerkiksi tulonhankinnan laittomuuksista ei puhuta; eikä myöskään ei-heterosuhteista (yleisessä konservatiivisessa ilmapiirissä). Myös traumaattisista ja epämiellyttävistä kokemuksista, esimerkiksi väkivallasta, vaietaan.

Tarkoituksenamme on jatkossa tarkastella haastatteluja sanomattoman näkökulmasta. Se saattaa avata meille uudenlaisen näkökulman näiden kyseisten nuorten elämään ja itsenäistymiseen. Joskaan ei ole ihan ongelmatonta tutkia sitä, mitä ei sanota. Ongelma herättää ennen 
kaikkea eettisiä pohdintoja. Emmekö me juuri ole korostaneet oikeutta olla vastaamatta, olla puhumatta jostakin? Onko meillä oikeutta tarttua siihen, mistä meille ei haluta puhuta?

\section{Lopuksi}

Kuten Pyyry (2012) on todennut, osallistaminen on ongelmallinen käsite, koska se sisältää ajatuksen toisen ihmisen aktivoimisesta tai jopa voimaannuttamisesta, "toimijuuden" tai "äänen" antamisesta toiselle. Samalla jätetään helposti huomioimatta nuorten omat tavat toimia tai käsitykset siitä, mikä on tärkeää tietoa. Hiljaisuuden ohella toinen asia, mihin tulemme jatkossa kiinnittämään systemaattista huomiota, on vertaisuus: puhutaanko meille aikuissosiologeille eri asioista ja/tai eri tavalla kuin kanssatutkijanuorille. Tähän emme osaa vielä tässä esseessä vastata. Mutta se on selvää, että kanssatutkimuksellisesta otteestamme huolimatta on tutkimustamme ohjannut tutkijan näkökulma ja tiedonintressi. Me aikuiset ja sosiologit olemme määrittäneet sen, mitä haluamme tietää eli sen, mikä on relevanttia tietoa. Niin sanotun kuin sanomattoman äärellä on hyvä pysähtyä pohtimaan, on se tieto "oikeaa" ja "totta" ja kenen näkökulmasta (vrt. Pyyry 2012).

On myös sanottava ääneen, että tutkimuksessamme nuoret ovat lähinnä osallistuneet haastatteluiden tekoon ja prosessin reflektioon. On siis katsottava peiliin ja pohdittava, löytyisikö kaikkien kannalta mielekäs tapa, jolla nuoret voisivat osallistua myös analyysiin ja näin ollen tuottamaan tuloksia.

Aiheellisesta itsekritiikistä huolimatta on loppuun todettava, että tähän asti tämä meille uudenlainen tutkimusprosessi on ollut niin meille kuin nuorille pääasiallisesti mielekäs ja monella tapaa opettavainen. Sijaishuollosta itsenäistyneiden nuorten parissa työskennellessä ilmiö, johon törmää liian usein, on stigma. Nuorten puheessa nousee esiin heidän arvostamisensa ja sen puute, heihin uskominen ja sen puute, leimaaminen ja leimautuminen, häpeä. Meille on tärkeää, että edes nämä muutamat kanssatutkijanuoret ovat hankkeessamme kokeneet, että heidän panoksensa hankkeessamme on äärimmäisen olennainen ja arvokas.

Nämä ja monenlaiset muut pohdinnat jatkuvat niin omassa tutkimuksessamme Venäjän kontekstissa kuin laajemminkin. Olemme tänä syksynä perustaneet eri suomalaisten yliopistojen tutkijoista koostuvaan kanssatutkimusverkoston, johon mukaan ovat tervetulleita kaikki, jotka käyttävät osallistavia tutkimusmenetelmiä tai ovat aikeissa tarttua niihin.

\section{Lähteet}

Bradbury-Jones, Caroline \& Taylor, Julie (2015), Engaging with children as co-researchers: challenges, counter challenges and solutions. - International Journal of Social Research Methodology 18:3, 161-173. DOI: 10.1080/13645579.2013.864589

Furlong, Andy (2013), Youth Studies. An Introduction. London: Routledge.

Kilpatrick, Rosemary, McCartan Claire, McAlister Siobhan \& McKeown Penny (2007), 'If I am brutally honest, research has never appealed to me'. The problems and successes of a peer research project. - Educational action research 15(3): 351-369. https://doi.org/10.1080/09650790701514291

Mazzei, Lisa A. (2007), Inhabited Silence in Qualitative Research: Putting Poststructural Theory to Work. New York: Peter Lang.

Pyry, Noora (2012), Nuorten osallisuus tutkimuksessa. Menetelmällisiä kysymyksiä ja vastausyrityksiä. - Nuorisotutkimus 1/2012, 35-53. http://urn.fi/URN:NBN:fi:ELE-1755275

Törrönen, Maritta \& Vauhkonen, Teemu (2012), Itsenäistyminen elämänvaiheena - osallistava vertaistutkimus sijaishuollosta itsenäistyvien nuorten hyvinvoinnista. Forssa: SOS Lapsikylä. https:// www.sos-lapsikyla.fi/.../user.../vertaistutkimus-SOS-Lapsikyla.pdf 